\title{
EVALUASI PELAKSANAAN PRAKTIK PEMBENTUKAN BAHAN BENGKEL FABRIKASI JURUSAN PENDIDIKAN TEKNIK MESIN FAKULTAS TEKNIK UNIVERSITAS NEGERI YOGYAKARTA
}

\author{
Arif Marwanto ${ }^{1}$, Aan Ardian $^{2}$, Suyanto $^{3}$ \\ Jurusan Pendidikan Teknik Mesin FT UNY \\ arif_marwanto@uny.ac.id
}

\begin{abstract}
The implementation of practice-work learning need to be evaluated periodically to determine wether the equipments and the learning methods are appropriate to the main purpose of learning, which is the establishment of learners' competency. The evaluation process in this research was carried out by adopting the CIPP evaluation methods. The research objects are lecturers and students participating in the Material Forming Practice course. Data were collected using documentation, observation and questionnaires and were analyzed using descriptive analysis. The results show that the implementation of Material Forming Practice course in the half semester of academic year 2016/2017 was very successful. Barriers faced by the lecturers were the lack of students' comprehension in flat pattern drawing, mathematical analysis skills, lack of motivation in reading jobsheet, and the lack of students' adaptation to the practice environment. Barriers faced by the students came from the lecturers, workpiece materials, low category workshop conditions, the shop equipments are in moderate category, whereas jobsheets and technicians are in the very low category. The condition of the equipments in terms of quantity is sufficient, but in terms of quality, many still needs repairs and renewals. The students' learning achiements in the midterm semester was the ability to finish 4 jobs with marks as follow: $53 \%$ were graded " $A$ ", $35 \%$ were graded " $B$ " and the remaining $12 \%$ were graded " $C$ ".
\end{abstract}

Keywords: evaluation, material forming practice

\begin{abstract}
ABSTRAK
Penelitian ini bertujuan untuk mengetahui kesesuaian peralatan dan pelaksanaan pembelajaran dengan tujuan akhir pembelajaran yaitu pembentukan kompetensi mahasiswa. Metode yang digunakan mengadopsi metode evaluasi CIPP. Objek penelitian adalah dosen pengampu dan mahasiswa peserta mata kuliah praktik Pembentukan Bahan tahun ajaran 2016/2017. Metode pengumpulan data menggunakan dokumentasi, observasi, dan angket. Data dianalisis dengan teknik analisis deskriptif. Hasil penelitian menunjukkan bahwa pelaksanaan praktik Pembentukan Bahan selama setengah semester terlaksana dengan sangat baik. Hambatan yang dialami dosen yaitu kurangnya kemampuan mahasiswa dalam memahami gambar bentangan, analisis matematika, adaptasi dengan lingkungan praktik, dan malas membaca jobsheet. Hambatan mahasiswa dari dosen, bahan, dan kondisi bengkel termasuk kategori rendah, alat termasuk kategori sedang, jobsheet dan teknisi termasuk kategori rendah sekali. Kondisi peralatan secara kuantitas mencukupi, tetapi kualitasnya perlu perbaikan dan peremajaan. Pada pertengahan semester mahasiswa mampu menyelesaikan 4 materi pekerjaan dengan perolehan nilai A sebanyak $53 \%$, nilai B sebanyak $35 \%$ dan nilai C sebanyak $12 \%$.
\end{abstract}

Kata kunci: evaluasi, praktik pembentukan bahan

\section{PENDAHULUAN}

Pendidikan merupakan salah satu usaha yang dapat dilakukan untuk meningkatkan kualitas sumber daya manusia. Kualitas pendidikan mempunyai kontribusi langsung pada peningkatan daya saing bangsa dalam bidang sumber daya manusia. Meningkatkan kualitas pendidikan tinggi merupakan pekerjaan yang cukup kompleks, karena menyangkut banyak faktor seperti kualitas pendidik dan tenaga kependidikan, kualitas sarana dan fasilitas pendidikan, sistem pengelolaan pendanaan, dan suasana akademik yang tercipta di dalam perguruan tinggi.

Jurusan Pendidikan Teknik Mesin Fakultas Teknik Universitas Negeri Yogyakarta (JPTM FT UNY) merupakan salah satu 
pendidikan tinggi kejuruan dalam bidang teknologi yang bertujuan menghasilkan lulusan yang berkualitas dan profesional di bidangnya. Dalam rangka memberikan layanan kepada mahasiswa untuk mencapai kompetensi, JPTM FT UNY selalu meningkatkan kualitas dan kenyamanan layanannya yang mendukung proses pembelajaran.

Keterampilan merupakan kecakapan yang harus dikuasai untuk menyelesaikan kerja (Kamus Besar Bahasa Indonesia, Depdikbud). Usaha untuk membentuk kompetensi harus dengan praktik yang dilakukan berulang-ulang sehingga akan terbentuk tindakan yang otomatis. Seseorang dikatakan memiliki kompetensi praktik jika telah menyelesaikan evaluasi keterampilan yang diberikan. Praktik merupakan cara melaksanakan secara nyata apa yang disebut dalam teori (Kamus Besar Bahasa Indonesia, Depdikbud). Pembelajaran praktik merupakan ciri khas bagi lembaga pendidikan teknologi kejuruan. Demikian juga bagi JPTM FT UNY sebagai lembaga pendidikan teknologi kejuruan, memiliki keunggulan yaitu proporsi pelaksanaan pembelajaran praktik lebih besar daripada pembelajaran teori. Berkaitan hal tersebut, dalam rangka memberikan kompetensi yang tinggi di bidang fabrikasi kepada mahasiswa, maka diselenggarakan mata kuliah Praktek Pembentukan Bahan.

Sumadi Suryabrata (1987: 249) menyatakan bahwa belajar merupakan suatu aktivitas yang menghasilkan perubahanperubahan pada diri pelajar, baik perubahan pada aspek kognitif, aspek afektif dan aspek psikomotorik ke arah kemajuan. Sehubungan dengan itu belajar belajar diartikan sebagai suatu usaha yang mengakibatkan perubahan tingkah laku yang ditandai timbulnya kecakapan baru. Pembelajaran praktik merupakan proses pembelajaran dengan memberikan kesempatan kepada anak didik untuk mengimplementasikan semua teori yang didapatkan di ruang kelas dengan menghadapi benda kerja secara langsung. Misalnya pada sekolah kejuruan, kelompok teknologi dan industri, anak didik diberi kesempatan untuk mengerjakan benda kerja mempergunakan mesin-mesin yang signifikan dengan jenis pekerjaannya. Menurut Ryan (1980 : 50) yang dikutip Dwi rahdiyanta (1991) menjelaskan bahwa hasil pembelajaran keterampilan dapat diukur pertama, dengan jalan memberikan penilaian terhadap tingkah laku siswa pada saat proses belajar sedang berlangsung. Kedua, dengan jalan memberikan tes kepada siswa diluar mengikuti pelajaran untuk mengukur keterampilan dan sikap siswa. Ketiga, beberapa waktu setelah berakhirnya pelajaran dilakukan penilaian Dari segi keberhasilan siswa dalam pekerjaan meliputi kondisi tempat kerja dan kualitas pekerjaan.

Berkaitan dengan upaya peningkatan mutu dan kualitas pembelajaran praktik, faktor kurikulum dan kelengkapan sarana yang digunakan dalam praktik sangat berkaitan, karena bagaimana baiknya kurikulum akan tergantung dari pelaksanaannya. Nana Syaodih (2007: 4) menjelaskan bahwa kurikulum merupakan seperangkat rencana pendidikan, memberikan pedoman dan pegangan tentang jenis, lingkup, dan urutan isi, serta proses pendidikan. Sedangkan menurut UndangUndang Sistem Pendidikan Nasional No. 20 tahun 2003, kurikulum adalah seperangkat rencana dan pengaturan mengenai tujuan, isi, dan bahan pelajaran serta cara yang digunakan sebagai pedoman penyelenggaraan kegiatan pembelajaran untuk mencapai tujuan pendidikan tertentu. Ketersediaan sarana dan prasarana serta pengajar yang berkualitas menjadi faktor penting dalam meningkatkan mutu dan kualitas pendidikan. Iklim pembelajaran yang dikembangkan oleh dosen mempunyai pengaruh yang besar terhadap keberhasilan belajar. Demikian pula kualitas dan keberhasilan pembelajaran sangat dipengaruhi oleh kemampuan dan ketepatan dosen dalam memilih dan menggunakan strategi pembelajaran. Mahasiswa mengalami kesulitan dalam mengikuti pelajaran karena metode pembelajaran yang dipilih dan digunakan oleh dosen tidak tepat. Pemilihan strategi pembelajaran yang sesuai dengan tujuan kurikulum dan potensi mahasiswa merupakan kemampuan dan keterampilan dasar yang harus dimiliki oleh seorang dosen. 
Matakuliah Praktek Pembentukan Bahan merupakan mata kuliah praktik yang mengajarkan keterampilan dan kompetensi di bidang fabrikasi. Mata kuliah ini memberi pengalaman praktik kepada mahasiswa dalam pembentukan bahan yang terdiri dari pengerjaan pelat dan tempa. Mahasiswa diberi pengalaman praktik dalam membuat gambar bukaan pelat, menentukan ukuran awal bahan, memotong, menekuk baik dengan tangan maupun mesin, melipat, mematri, mengebor, mengeling, merangkai, menyambung, memberi penguatan tepi, mengelas titik, mengerol dan finishing. Mahasiswa juga diberi pengalaman praktik dalam bidang penempaan meliputi ukuran awal bahan, langkah penempaan, pemanasan, pemipihan, penggembungan, penekukan, pelancipan dan pembentukan akhir sesuai dengan ukuran. Hal ini menunjukkan bahwa mata kuliah ini memiliki peran strategis yang akan menentukan ciri khas jurusan pemesinan. Oleh karena itu, pembelajaran harus benar-benar mampu menanamkan dasar-dasar yang kuat tentang praktik. Dengan penguasaan materi yang memadai akan menunjang mahasiswa dalam pelaksanaan praktik. Keberhasilan mahasiswa menguasai kompetensi pada matakuliah ini akan turut meningkatkan kualitas hasil pendidikan yang dihasilkan.

Pembelajaran praktik merupakan suatu proses untuk meningkatkan keterampilan. Pembelajaran praktik yang merupakan bagian pembelajaran kompetensi yang membentuk kemampuan terutama pada ranah psikomotor dan sikap, memerlukan pengelolaan kelas praktik agar peserta didik mendapat kesempatan mengalami pembelajaran yang sama baik dari jenis kompetensi yang dipelajarinya maupun kesempatan untuk menggunakan fasilitas praktik. Pembelajaran praktik menjadi satu aspek penting untuk peningkatan kompetensi keahlian anak didik, khususnya untuk pendidikan kejuruan.

Sebagai lembaga pendidikan tinggi kejuruan di bidang teknologi, JPTM FT UNY dituntut untuk menghasilkan lulusan yang kompeten dan mampu bersaing dalam lapangan kerja. Untuk meningkatkan mutu lulusannya, saat ini pihak jurusan sedang gencar-gencarnya berusaha, antara lain meningkatkan sarana dan prasarana serta menyempurnakan dan mengembangkan kurikulum yang harus disesuaikan dengan kebutuhan dunia kerja, sehingga dunia kerja dan dunia pendidikan diharapkan bisa saling mengevaluasi terhadap kekurangan yang dimiliki dari keduanya.

Evaluasi sangat perlu untuk dilaksanakan, sehingga didapatkan masukan atau data-data yang merupakan kelebihan atau kekurangan yang masih ada, hal-hal yang masih harus dilakukan, program-program yang telah terlaksana dan yang harus diperbaiki, sebagai bahan yang dapat digunakan untuk menyusun program selanjutnya. Salah satu rumusan mengenai evaluasi menyatakan bahwa evaluasi adalah perbuatan pertimbangan berdasarkan seperangkat kriteria yang disepakati dan dipertanggungjawabkan. Dalam hal ini terdapat tiga faktor utama yang terdapat pada evaluasi yaitu : Pertimbangan (Judgement), Diskripsi obyek penelitian, Kriteria yang dapat dipertanggungjawabkan.(Oemar Hamalik 1993 :2)

Dalam arti luas evaluasi adalah suatu proses perencanaan, memperoleh, dan menyediakan informasi yang sangat diperlukan dalam membuat alternatif-alternatif keputusan. Sesuai dengan pengertian tersebut maka setiap kegiatan evaluasi atau penilaian merupakan suatu proses yang sengaja direncanakan untuk memperoleh informasi atau data. Berdasarkan data tersebut kemudian dibuat suatu keputusan (M. Ngalim Purwanto 1994 : 3). Berhubungan dengan pembelajaran praktik Pembentukan Bahan yang mengutamakan kompetensi di bidang fabrikasi, selama ini telah terlaksana dengan baik, namun masih dirasakan ada beberapa kekurangan yang harus disempurnakan, agar tujuan pembelajaran yang telah ditetapkan dapat tercapai.

Dalam rangka mencapai tujuan tersebut perlu dicari hal-hal yang menghambat dan mendukung usaha ke arah tersebut. Hal ini dapat dilakukan dengan mencari komponenkomponen yang mempengaruhi proses pembelajaran, dalam hal ini pembelajaran 
praktik Pembentukan Bahan. Sehingga proses pembelajaran menjadi sangat penting untuk dikaji atau di evaluasi dalam rangka adanya keseimbangan antara pihak industri selaku pengguna lulusan dan pihak jurusan sebagai penghasil lulusan.

Dalam upaya mengevaluasi proses pembelajaran, semua faktor yang berhubungan dengan proses pembelajaran merupakan hal yang sangat penting untuk dibahas, adapun faktor-faktor tersebut antara lain: metode pembelajaran yang digunakan, kurikulum yang dipakai, lingkungan kelas/bengkel, media dan kelengkapan alat-alat untuk praktik, serta motivasi belajar mahasiswa.

Berdasarkan permasalahan yang timbul, dapat dirumuskan permasalahan penelitian sebagai berikut: (1) Bagaimanakah pelaksanaan pembelajaran praktik Pembentukan Bahan dilihat dari kurikulum yang digunakan? (2) Apa saja hambatan yang dialami Dosen, dalam proses pembelajaran praktik Pembentukan Bahan? (3) Apa saja hambatan yang dialami mahasiswa, dalam proses pembelajaran praktik Pembentukan Bahan?

Bagaimanakah kondisi peralatan praktik Pembentukan Bahan yang digunakan dalam proses pembelajaran? (5) Bagaimana prestasi mahasiswa dalam perkuliahan praktik Pembentukan Bahan?

\section{METODE}

Model evaluasi yang digunakan adalah model CIPP. Model Evaluasi CIPP (Context, Input, Process, Product) adalah model evaluasi yang dikembangkan oleh Stufflebeam dan Shinkfield (1985: 155-156) yang menyatakan bahwa model evaluasi CIPP bermanfaat dalam 4 tipe pengambilan keputusan, yaitu (1) Context evaluation as a mean of servicing planning decisions, (2) Input evaluation these structuring decisions, (3) Process evaluation to guide implementing, (4) Product evaluations to serve recycling decisions.

Karena keterbatasan peneliti, maka dalam penelitian ini komponen yang dievaluasi adalah process dan product. Untuk proses dievaluasi jalannya proses pembelajaran termasuk hambatannya, dan untuk evaluasi produk dievaluasi prestasi mahasiswa setelah mengikuti pembelajaran. Metode yang digunakan untuk mengevaluasi adalah secara deskriptif kuantitatif. Penelitian ini juga bersifat exploratif yang bertujuan untuk menggambarkan keadaan atau mencari fakta dan keterangan faktual.

Prosedur evaluasi yang dijalankan adalah sebagai berikut: (1) Menyiapkan instrumen evaluasi, (2) Menentukan sampel penelitian, (3) Pelaksanaan proses evaluasi dengan menggunakan instrumen yang telah disusun, (4) Pengolahan data hasil evaluasi, (5) Perumusan rekomendasi berdasarkan hasil evaluasi, (5) Proses pelaporan.

Penelitian ini merupakan penelitian populasi. Populasi dalam penelitian ini adalah dosen pengajar praktik pembentukan bahan dan mahasiswa JPTM FT UNY yang mengikuti perkuliahan praktik pembentukan bahan. Tempat penelitian ini adalah bengkel fabrikasi JPTM FT UNY.

Metode pengumpulan data dalam penelitian ini adalah menggunakan teknik observasi, dokumentasi dan angket dengan menggunakan lembar instrumen yang telah disusun. Teknik analisis data dalam penelitian ini menggunakan teknik deskriptif kuantitatif. Analisis deskriptif dilakukan untuk menggambarkan kondisi atau keadaan faktual hasil evaluasi, sedangkan analisis kuantitatif dilakukan untuk memberikan skor penilaian dari hasil evaluasi yang dilakukan.

Cara atau pedoman yang dipakai dalam pengambilan keputusan adalah standar umum yang sering dipakai, yaitu:

$$
\begin{array}{ll}
76-100 \% & \text { : Baik } \\
56-75 \% & \text { : Cukup } \\
40-55 \% & \text { : Kurang Baik } \\
0-39 \% & \text { : Tidak baik (Riduwan, 2009) }
\end{array}
$$

Sedangkan untuk pengkategorian dalam mengungkap data keterlaksanaan program adalah:

Terlaksana $<20 \% \quad$ : Sangat kurang 


$$
\begin{array}{ll}
\text { Terlaksana } 21-40 \% & \text { : Kurang } \\
\text { Terlaksana } 41-60 \% & \text { : Cukup } \\
\text { Terlaksana } 61-80 \% & \text { : Baik } \\
\text { Terlaksana } 81-100 \% & \text { : Baik Sekali }
\end{array}
$$

Teknik analisis kecenderungan hambatan mahasiswa dan dosen dalam pelaksanaan praktik pembentukan bahan didasarkan pada skor ideal dengan ketentuan:

$$
\begin{array}{ll}
>\mathrm{Mi}+1,5 \mathrm{SDi} \text { : Tinggi } & \\
\mathrm{Mi}-(\mathrm{Mi}+\mathrm{SDi}) & : \text { Sedang } \\
(\mathrm{Mi}-1,5 \mathrm{SDi})-\mathrm{Mi} & : \text { Rendah } \\
<(\mathrm{Mi}-1,5 \mathrm{SDi}) & : \text { Rendah Sekali }
\end{array}
$$

Keterangan:

$$
\begin{aligned}
\mathrm{Mi} & =\begin{array}{l}
\text { Mean ideal yang dicapai } \\
\text { instrumen }
\end{array} \\
\mathrm{SDi} & =\begin{array}{l}
\text { Simpangan Baku ideal yang } \\
\text { dicapai instrumen }
\end{array}
\end{aligned}
$$

\section{HASIL DAN PEMBAHASAN}

Pengumpulan data pelaksanaan struktur program dilakukan dengan dokumentasi. Data pelaksanaan struktur program praktik pembentukan bahan disampaikan secara rinci disampaikan dalam Tabel 1.

Tabel 1. Pelaksanaan praktik pembentukan bahan semester gasal 2016/2017

\begin{tabular}{lccccccccc}
\hline \multirow{2}{*}{ Sasaran Evaluasi } & \multicolumn{1}{c}{ Pencapaian Kelas } \\
\cline { 2 - 9 } & A1 & A2 & B1 & B2 & C1 & C2 & D1 & D2 \\
\hline $\begin{array}{l}\text { Jumlah jam menurut } \\
\text { kurikulum }\end{array}$ & 48 & 48 & 48 & 48 & 48 & 48 & 48 & 48 \\
\hline Jumlah jam per minggu & 6 & 6 & 6 & 6 & 6 & 6 & 6 & 6 \\
\hline Jumlah minggu efektif & 8 & 7 & 8 & 7 & 8 & 8 & 8 & 8 \\
\hline $\begin{array}{l}\text { Jumlah jam tatap muka } \\
\text { yang dilaksanakan }\end{array}$ & 48 & 42 & 48 & 42 & 48 & 48 & 48 & 48 \\
$\begin{array}{l}\text { Persentase pencapaian } \\
(1 / 2 \text { semester) }\end{array}$ & 100 & 87,5 & 100 & 87,5 & 100 & 100 & 100 & 100 \\
\hline
\end{tabular}

Pengambilan data kelengkapan sarana praktik dilakukan dengan observasi serta melihat dokumentasi tentang daftar inventaris alat di bengkel. Fasilitas kelengkapan alat difokuskan pada kelengkapan alat/mesin pembentukan bahan, alat bantu dan alat ukur. Selanjutnya kondisi peralatan praktik pembentukan bahan dapat dilihat pada Tabel 2 .
Tabel 2.Kondisi Peralatan Praktik Pembentukan Bahan

\begin{tabular}{llccc}
\hline \multirow{2}{*}{ Nama } & & \multirow{2}{*}{ Jumlah } & \multicolumn{3}{r}{ Kondisi } \\
\cline { 3 - 5 } & & & Baik & Rusak \\
\hline \multirow{4}{*}{ Peralatan/ } & Bending hidrolik & 1 & 0 & 1 \\
Mesin Utama & Rending mekanik & 2 & 2 & 0 \\
pembentukan & Rol profil & 2 & 2 & 0 \\
bahan & Rol kerucut & 2 & 2 & 1 \\
& Potong hidrolik & 1 & 1 & 0 \\
& Potong mekanik & 2 & 2 & 0 \\
& Dapur tempa & 4 & 3 & 1 \\
& Mesin las tahanan & 1 & 1 & 0 \\
& Gunting & 3 & 2 & 1 \\
\hline \multirow{5}{*}{ Alat Bantu } & Palu plastik & 6 & 4 & 0 \\
& Palu kayu & 6 & 6 & 0 \\
& Palu logam & 10 & 10 & 0 \\
& Riveter & 2 & 2 & 0 \\
& Landasan & 40 & 40 & 0 \\
& Peralatan patri & 4 & & \\
\hline \multirow{5}{*}{ Alat } & Mistar baja $30 \mathrm{~cm}$ & 10 & 10 & 0 \\
Menggambar & Mistar baja $60 \mathrm{~cm}$ & 4 & 4 & 0 \\
& Penitik & 5 & 5 & 0 \\
& Penggores & 2 & 2 & 0 \\
& Mistar busur & 4 & 4 & 0 \\
& Penyiku & 5 & 5 & 0 \\
& Bevel protactor & 2 & 2 & 0 \\
& Jangka sorong & 2 & 2 & 0 \\
\hline
\end{tabular}

Pelaksanaan evaluasi jalannya proses pembelajaran dilakukan dengan mencari hambatan-hambatan yang terjadi dan mengganggu proses pembelajaran. Angket diberikan kepada dosen dan mahasiswa untuk mendapatkan data hambatan apa saja yang mereka alami selama proses pembelajaran. Identifikasi hambatan yang dialami mahasiswa dalam pelaksanaan praktik pembentukan bahan menggunakan skor rerata ideal (Mi) dan simpangan baku ideal (SDi) sebagai kriteria pembanding.

Jumlah butir pada variabel hambatan yang bersumber dari dosen sebanyak 5 butir dan secara teoritis mempunyai rentang skor antara 0 sampai 5 dengan rerata ideal 2,5 dan simpangan baku ideal 0,83. Dari harga-harga tersebut maka kecenderungan hambatan mahasiswa yang bersumber dari dosen dapat dikategorikan sebagai berikut:

$$
\begin{array}{ll}
3,745 \text { ke atas } & \text { : Tinggi } \\
2,5-3,745 & : \text { Sedang } \\
1,255-2,5 & : \text { Rendah } \\
<1,255 & : \text { Rendah sekali }
\end{array}
$$

Berdasarkan data yang telah terkumpul, 
diperoleh rerata sebesar 2,19. Berdasarkan range kategori yang telah ditentukan, maka hambatan mahasiswa yang bersumber dari dosen termasuk dalam kategori rendah.

Jumlah butir pada variabel hambatan yang bersumber dari peralatan praktik sebanyak 5 butir dan secara teoritis mempunyai rentang skor antara 0 sampai 5 dengan rerata ideal 2,5 dan simpangan baku ideal 0,83. Dari hargaharga tersebut maka kecenderungan hambatan mahasiswa yang bersumber dari peralatan praktik dapat dikategorikan sebagai berikut:

$\begin{array}{ll}3,745 \text { ke atas } & \text { : Tinggi } \\ 2,5-3,745 & \text { : Sedang } \\ 1,255-2,5 & \text { : Rendah } \\ <1,255 & \text { : Rendah sekali }\end{array}$

Berdasarkan data yang telah terkumpul, diperoleh rerata sebesar 2,99. Berdasarkan range kategori yang telah ditentukan, maka hambatan mahasiswa yang bersumber dari peralatan praktik termasuk dalam kategori sedang.

Jumlah butir pada variabel hambatan yang bersumber dari bahan praktik sehanyak 3 butir dan secara teoritis mempunyai rentang skor antara 0 sampai 3 dengan rerata ideal 1,5 dan simpangan baku ideal 0,5. Dari harga harga di atas maka kecenderungan hambatan mahasiswa yang bersumber dari bahan praktik dapat dikategorikan sebagai berikut:

$$
\begin{array}{ll}
2,25 \text { ke atas } & \text { : Tinggi } \\
1,5-2,25 & \text { : Sedang } \\
0,75-1,5 & \text { : Rendah } \\
<0,75 & \text { : Rendah sekali }
\end{array}
$$

Berdasarkan data yang telah terkumpul, diperoleh rerata sebesar 0,96. Berdasarkan range kategori yang telah ditentukan, maka hambatan mahasiswa yang bersumber dari bahan praktik termasuk dalam kategori Rendah.

Jumlah butir pada variabel hambatan yang bersumber dari kondisi bengkel sebanyak 6 butir dan secara teoritis mempunyai rentang skor antara 0 sampai 6 dengan rerata ideal 3 dan simpangan baku ideal 1. Dari harga - harga diatas maka kecenderungan hambatan mahasiswa yang bersumber dari kondisi bengkel dapat dikategorikan sebagai berikut:

4,5 ke atas : Tinggi
$3-4,5:$ Sedang
$1,5-3 \quad:$ Rendah
$<1,5 \quad:$ Rendah sekali

Berdasarkan data yang telah terkumpul, diperoleh rerata sebesar 0,94. Berdasarkan range kategori yang telah ditentukan, maka hambatan mahasiswa yang bersumber dari kondisi bengkel termasuk dalam kategori rendah.

Jumlah butir pada variabel hambatan yang bersumber dari jobsheet sebanyak 4 butir dan secara teoritis mempunyai rentang skor antara 0 sampai 4 dengan rerata ideal 2 dan simpangan baku ideal 0,66. Dari harga -harga diatas maka kecenderungan hambatan mahasiswa yang bersumber dari job sheet dapat dikategorikan sebagai berikut:

$$
\begin{aligned}
& 2,99 \text { ke atas : Tinggi } \\
& 2-2,99: \text { Sedang } \\
& 1,01-2: \text { Rendah } \\
& <1,01 \quad \text { Rendah sekali }
\end{aligned}
$$

Berdasarkan data yang telah terkumpul, diperoleh rerata sebesar 0,91. Berdasarkan range kategori yang telah ditentukan, maka hambatan mahasiswa yang bersumber dari job sheet termasuk dalam kategori rendah sekali.

Jumlah butir pada variabel hambatan yang bersumber dari teknisi/toolman sebanyak 3 butir dan secara teoritis mempunyai rentang skor antara 0 sampai 3 dengan rerata ideal 1,5 dan simpangan baku ideal 0,5. Dari harga-harga di atas maka kecenderungan hambatan mahasiswa yang bersumber dari tool man dapat dikategorikan sebagai berikut:

$$
\begin{array}{ll}
2,25 \text { ke atas } & \text { : Tinggi } \\
1,5-2,25 & \text { : Sedang } \\
0,75-1,5 & \text { : Rendah } \\
<0,75 & \text { : Rendah sekali }
\end{array}
$$

Berdasarkan data yang telah terkumpul, diperoleh rerata sebesar 0,92. Berdasarkan range kategori yang telah ditentukan, maka hambatan mahasiswa yang bersumber dari toolman termasuk dalam kategori rendah.

Hasil dari angket yang diberikan 
menunjukkan ada beberapa hambatan yang dialami dosen dalan pelaksanaan praktik pembentukan bahan. Hambatan tersebut bersumber dari mahasiswa, peralatan praktik, bahan praktik, kondisi lingkungan bengkel, dan materi praktikum/kurikulum.

Hambatan dalam pelaksanaan praktik pembentukan bahan yang dialami dosen dan bersumber dari mahasiswa yaitu mahasiswa kurang memahami gambar bentangan, kemampuan analisis matematika/logika masih rendah, malas membaca jobsheet dan lebih senang bertanya kepada teman, pemahaman penggunaan peralatan praktik kurang baik, kurang memahami suasana kerja (sebagian besar dari luluan SMU).

Dari sisi peralatan praktik, hambatan yang dialami dosen yaitu: banyak terjadi kerusakan pada peralatan sehingga berfungsi tidak maksimal, jangka sorong sangat kurang, palu plastik sudah rusak/pecah, baut solder lepas sehingga tidak maksimal penggunaannya, perlunya peremajaan peralatan tangan secara menyeluruh. Hambatan dari sisi bahan praktik tidak ditemukan, cukup memadai digunakan dalam praktik. pada sisi kondisi lingkungan bengkel, terdapat kendala karena kurangnya meja kerja dibandingkan dengan jumlah mahasiswa dalam satu sesi praktikum, suasana kerja terlalu padat dan tidak ada tempat memadai untuk briefing.

Hambatan yang dialami dosen yang bersumber dari materi praktikum/kurikulum yaitu: gambar kerja pada jobsheet yang kurang jelas, dalam materi kerja sambungan lipat perlu lebih runtut, perlunya pengembangan job baru agar lebih bervariasi.

Pencapaian nilai akhir praktik oleh mahasiswa terangkum dalam Tabel 3 . Berdasarkan dari hasil dokumentasi dapat dilihat bahwa pelaksanaan struktur program praktik pembentukan bahan JPTM FT UNY pada semester genap tahun 2016/2017 sampai dengan pertemuan ke 8/setengah semester persentase pencapaiannya adalah $100 \%$ untuk kelas A1, B1, C1, C2, D1, dan D2, sedangkan untuk kelas A2 dan B2 persentase pencapaiannya $87,5 \%$. Persentase diperoleh dengan cara membagi jumlah jam tatap muka yang berhasil dilaksanakan dengan jumlah jam pembelajaran menurut kurikulum dikali $100 \%$. Ketercapaian yang tidak sampai $100 \%$ disebabkan karena terkena libur nasional, dimungkinkan untuk mencari waktu pengganti.

Tabel 3. Penyebaran nilai mahasiswa

\begin{tabular}{|c|c|c|c|c|c|c|c|c|c|c|}
\hline \multirow{2}{*}{ Nilai } & \multicolumn{8}{|c|}{ Kelas } & \multirow{2}{*}{$\mathrm{Jml}$} & \multirow{2}{*}{$\%$} \\
\hline & $\mathrm{A} 1$ & $\mathrm{~A} 2$ & B1 & B2 & $\mathrm{C} 1$ & $\mathrm{C} 2$ & D1 & D2 & & \\
\hline $\mathrm{A}$ & 3 & 1 & 0 & - & 0 & 2 & 3 & - & 9 & $8 \%$ \\
\hline A- & 6 & 10 & 5 & - & 0 & 11 & 9 & - & 51 & $45,5 \%$ \\
\hline $\mathrm{B}+$ & 0 & 6 & 7 & - & 7 & 5 & 4 & - & 29 & $25,8 \%$ \\
\hline B & 0 & 0 & 5 & - & 4 & 0 & 2 & - & 11 & $9,8 \%$ \\
\hline B- & 0 & 0 & 3 & - & 7 & 0 & 0 & - & 10 & $8,9 \%$ \\
\hline $\mathrm{C}+$ & 0 & 0 & 0 & - & 1 & 0 & 0 & - & 1 & $0,9 \%$ \\
\hline $\mathrm{C}$ & 0 & 0 & 0 & - & 0 & 1 & 0 & - & 1 & $0,9 \%$ \\
\hline Jumlah & 19 & 17 & 20 & 0 & 19 & 19 & 18 & 0 & 12 & $100 \%$ \\
\hline
\end{tabular}

Berdasarkan tabel kondisi peralatan praktik pembentukan bahan, maka peralatan dibedakan menjadi tiga jenis yaitu: (1) alat utama pembentukan bahan, (2) alat bantu, (3) alat menggambar kerja. Secara kuantitas peralatan yang ada sudah mencukupi kebutuhan pelaksanaan praktikum, namun dari segi kualitas peralatan diperlukan perbaikan dan peremajaan. Kondisi peralatan yang sudah tidak $100 \%$ dapat mengganggu proses praktikum. Oleh karena itu, mendesak untuk dilakukan peremajaan peralatan pembentukan bahan.

Dalam pelaksanaan pembelajaran praktikum, hambatan dibagi menjadi 2 yaitu yang dialami/dirasakan oleh mahasiswa dan Dosen. Kendala yang dihadapi mahasiswa terbagi menjadi 6 variabel yang dapat diuraikan sebagai berikut.

Hambatan yang dirasakan mahasiswa yang bersumber dari dosen berada pada kategori rendah. Keluhan mahasiswa antara lain adanya dosen yang meninggalkan perkuliahan karena kepentingan akademik maupun non akademik semisal melakukan sidang ujian proyek akhir/atau rapat jurusan/fakultas maupun unit kegiatan lain. Hambatan yang datang dari peralatan praktik masuk kategori 
sedang, antara lain terkait masalah peralatan yang tidak berfungsi $100 \%$ optimal atau kondisi peralatan yang sudah rusak. Hambatan yang datang dari bahan praktik berada pada kategori rendah. Keluhan mahasiswa adalah jika terjadi kesalahan pengerjaan tidak ada bahan pengganti. Hambatan yang berasal dari kondisi bengkel berada pada kategori rendah yaitu permasalahan sempitnya kondisi ruang praktik pembentukan sehingga mengganggu mobilitas mahasiswa dan dosen selama prkatikum. Hambatan yang berasal dari joosheet atau lembar berkategori rendah sekali antara lain karena kurang lengkapnya petunjuk kerja (memang dibuat demikian untuk proses belajar mahasiswa) dan hambatan terakhir yaitu datang dari toolman/teknisi kategori rendah sekali.

Hambatan yang dialami Dosen selama pembelajaran praktik pembentukan bahan yang berasal dari mahasiswa yaitu mahasiswa kurang memahami gambar bentangan, kemampuan analisis matematika/logika masih rendah, malas membaca jobsheet dan lebih senang bertanya kepada teman, pemahaman penggunaan peralatan praktik kurang baik, kurang memahami suasana kerja/terbiasa bekerja (sebagian besar dari luluan SMU). Adanya hambatan ini menuntut dosen memiliki kreativitas mengelola pembelajaran serta selalu melakukan kontrol pengawasan dalam pembelajaran. Hambatan yang berasal peralatan berupa kondisi peralatan yang sudah tidak $100 \%$ bisa digunakan dalam pembelajaran, perlu adanya peremajaan peralatan. Untuk hambatan luas ruangan perlu pemikiran tentang tata letak peralatan bengkel. Hambatan yang berasal dari bahan praktik tidak ada karena dari segi kualitas dan kuantitas mencukupi untuk kegiatan pembelajaran. Sedang permasalahan materi perlunya penambahan variasi pekerjaan untuk meningkatkan kompetensi yang diberikan kepada mahasiswa.

Pencapaian nilai hasil belajar praktik pembentukan bahan mahasiswa semester gasal tahun ajaran 2016/2017 (Sampai dengan pertengahan semester $/ 8 \mathrm{x}$ pertemuan) yang terdiri dari 112 mahasiswa adalah $8 \%$ nilai A,
45,5\% nilai $\mathrm{A}-, 25,8 \%$ nilai $\mathrm{B}+$, dan $9,8 \%$ nilai $\mathrm{B}, 8,9 \%$ nilai $\mathrm{B}-, 0,9$ nilai $\mathrm{C}+$ dan 0,9 nilai $\mathrm{C}$ menunjukan keberhasilan proses pembelajaran praktikum pembentukan bahan di jurusan pendidikan teknik mesin FT UNY . Walaupun mengalami banyak kendala tetapi tidak mengurangi keberhasilan pelaksanaan pembelajaran. Hal ini dimungkinkan karena keseriusan Dosen dalam membimbing mahasiswa mengerjakan semua tugas praktikum pembentukan bahan.

\section{SIMPULAN}

Berdasarkan hasil penelitian, dapat diambil kesimpulan sebagai berikut: (1) Pelaksanaan pembelajaran praktik pembentukan bahan selama setengah semester ( $8 x$ pertemuan) dilaksanakan dengan persentase pelaksanaan sebesar $100 \%$, untuk 6 kelas, dan 87,5\% untuk 2 kelas. Sehingga pelaksanaan struktur program kurikulum tersebut termasuk dalam kategori sangat baik. (2) Hambatan yang dialami dosen dalam pelaksanaan praktik pembentukan bahan di Jurusan Pendidikan Teknik Mesin UNY yaitu: (a) Kurangnya kemampuan mahasiswa memahami gambar bentangan, kemampuan analisis matematika, malas membaca jobsheet, serta kurangnya adaptasi mahasiswa dengan lingkungan/suasana praktik, (b) Kurangnya kepedulian mahasiswa terhadap keselamatan kerja pada mesin, (c) Luas ruangan perlu pemikiran tentang tata letak peralatan bengkel, (d) Adanya peralatan yang perlu dilakukan peremajaan karena sudah tidak berfungsi optimal, (e) Penambahan variasi pekerjaan untuk meningkatkan kompetensi mahasiswa. (3) Hambatan yang dialami mahasiswa dalam pelaksanaan praktik pembentukan bahan di Jurusan Pendidikan Teknik Mesin yaitu: (a) Bersumber dari bahan praktik termasuk dalam kategori rendah, (b) Bersumber dari peralatan praktik termasuk dalam kategori sedang, (c) Bersumber dari dosen termasuk dalam kategori rendah, (d) Bersumber dari kondisi lingkungan bengkel termasuk dalam kategori rendah, (e) Bersumber dari job sheet termasuk dalam kategori rendah sekali, (f) Bersumber dari 
teknisi yang termasuk dalam kategori rendah sekali. (4) Kelengkapan peralatan praktik pembentukan bahan di Jurusan Pendidikan Teknik Mesin UNY diinterpretasikan seimbang dengan jumlah mahasiswa yang melaksanakan praktikum dalam satu season. Sehingga secara keseluruhan ketersediaan peralatan praktik pembentukan bahan yang tersedia di bengkel fabrikasi Jurusan Pendidikan Teknik Mesin UNY diinterpretasikan cukup memadai dari sisi kuantitas, namun dari sisi kualitas perlu perbaikan dan peremajaan untuk peralatan yang sdh tidak berfungsi optimal / rusak. (5) Prestasi mahasiswa setelah mengikuti praktik pembentukan bahan yang dilihat dari penilaian benda kerja hasil praktik mahasiswa adalah sangat baik, dimana 53\% mahasiswa yang mengikuti praktikum memiliki nilai "A", 35\% mendapatkan nilai "B", dan $12 \%$ mendapatkan nilai " $\mathrm{C}$ " hal ini menunjukkan meskipun mendapatkan beberapa hambatan namun mahasiswa mampu menyelesaikan pekerjaannya dengan baik.

\section{DAFTAR RUJUKAN}

Dwi Rahdiyanta, (1991). Kesiapan kerja siswa STM sebagai teknisi industri. Tesis Program Pasca Sarjana IKIP Jakarta.

M. Ngalim Purwanto, (1994). Prinsip-prinsip dan teknik evaluasi pengajaran. Bandung: Remaja Rosdakarya.

Nana Syaodih Sukmadinata, (2007). Pengembangan Kurikulum. Bandung: Remaja Rosdakarya.

Oemar Hamalik, (1993). Evaluasi kurikulum. Bandung: Remaja Rosdakarya.

Stufflebeam, D.L. \& Shinkfield, A.J. (1985). Systematic evaluation. Massachusetts: Kluwer-Nijhoff Publishing.

Sumadi Suryabrata, (1987). Psikologi Pendidikan. Yogyakarta: CV. Rajawali.

Kamus Besar Bahasa Indonesia. Jakarta: Balai Pustaka.

UU RI No. 20 Tahun 2003

Tentang Sistem Pendidikan Nasional. 